\title{
Design of experiments for the optimization of biochemical treatment of tannery wastewater
}

\begin{abstract}
The present work is concerned with the finding of the optimum conditions for biochemical wastewater treatment for a local tannery. The water samples were taken from outline areas (the wastewater of the chrome and vegetable tannery) in equal volumes and subjected to sedimentation, biological treatment, chemical and natural sedimentation treatment. The Box-Wilson method of experimental design was adopted to establish relationships between three operating variables that affect the treatment processes (temperature, aeration period and phosphate concentration) and the Biochemical Oxygen Demand (BOD5). The experimental data collected by this method were successfully fitted to a second order polynomial mathematical model. The most favorable operating conditions for the treatment were; a temperature, $32.5^{\circ} \mathrm{C}$, 10hours aeration period and phosphate concentration of $16.8 \mathrm{mg} / \mathrm{L}$. On using the optimum conditions a mathematical model simulating the operation for the treatment was obtained.
\end{abstract}

Keywords: activated sludge, biological treatment, experimental design, optimization, tannery wastewater
Volume 5 Issue 4 - 2017

Barbooti MM,' Ibrahim NK, ${ }^{2}$ Alwan $\mathrm{AH}^{2}$

'Department of Applied Sciences, University of Technology, Iraq ${ }^{2}$ Department of Chemical Engineering, University of Technology, Iraq

Correspondence: Barbooti MM, Department of Applied Sciences, University of Technology, P.O. Box 35045, Baghdad, Iraq, Email brbt2m@gmail.com

Received: June 30, 2017 | Published: October 12, 2017

\section{Introduction}

Almost all tanneries are located on rivers to provide them with process water ( 30 to $80 \mathrm{~m}^{3}$ for 1 ton of processed raw skins $)^{1}$ and for the disposal of their effluents. The effluent from this industry is mainly waterborne. ${ }^{2}$ The components of the effluent arise from purification of raw hides and skins before processing as well as from residual chemicals from the production processes. Hence, the tanning industry had been recognized as a major contributor to water pollution problems. Biodegradable organic matter consumes oxygen and nutrients in complex biochemical reactions until rendered inert. ${ }^{3}$ This exerts a biochemical oxygen demand as one of the fundamental parameters used to regulate the quality of the effluent. ${ }^{4}$

The contaminants in industrial wastewater are removed by physical, chemical and biological means. ${ }^{5,6}$ Facilities for handling wastewater are usually considered to have three major parts: collection, treatment and disposal. ${ }^{7}$ Pre-aeration is used to "freshen" the wastewater and to assist the removal of oil and grease. ${ }^{8}$ Secondary treatment processes commonly consist of biological processes. This means that living organisms which control the environment of the process are used to partially stabilize (oxidize) organic matter not previously removed by treatment processes and to convert it into a form which is easier to remove from the wastewater. ${ }^{9}$

Sedimentation or primary treatment makes the wastewater much clearer. Two clarifiers are used ${ }^{10}$ to provide detention time (3h) where, almost $60 \%$ of the suspended solids (SS) will either settle to the bottom or float to the surface and be removed. Removal of these solids will usually reduce the BOD5 of the waste approximately $35 \%$.

The next step is the biological treatment which can typically be divided into aerobic and anaerobic. Anaerobic biological treatment is an oxygen-devoid process. Aerobic biological treatment is done in the presence of oxygen. It is applicable to wastewater containing bio-degradable organic constituents and some non-metallic inorganic constituents. ${ }^{11}$
The activated sludge process (ASP) is the currently used biological treatment process for wastewater in Al-Za'afaraniya tanning factory, southern Baghdad. The system consists of an equalization basin, a settling tank, an aeration basin, a clarifier, and a sludge line. The recirculation of the biomass, which is an integral part of the process, allow microorganisms to adapt changes in wastewater composition with relatively short acclimation time and also allow a greater degree of control over acclaimed bacterial population. ${ }^{12}$ For a proper control of the ASP, the growth of the micro-organisms should be controlled. Bacteria make up about $95 \%$ of the activated sludge biomass. These single celled organisms grow in the wastewater by consuming (eating) biodegradable materials such as proteins, carbohydrates, fats and many other compounds. Some important factors acting on growth and activity of bacteria in biochemical wastewater treatment are: foodto-microorganism ratio $(\mathrm{F} / \mathrm{M})$; use of oxygen; ${ }^{13}$ formation of Floc; ${ }^{14}$ mixing. ${ }^{15} \mathrm{pH} ;{ }^{16}$ temperature ${ }^{6}$ and the effect of nutrients. ${ }^{16}$

Biological oxygen demand (BOD) is a measure of the oxygen used by microorganisms to decompose this waste. A large quantity of organic waste in the water requires large amount of bacteria to decompose it. Thus, the demand for oxygen will be high (high level of BOD). As the waste is consumed or dispersed through the water, BOD levels will begin to decline. ${ }^{17}$

Nitrates and phosphates in a body of water can contribute to high BOD levels. Nitrates and phosphates are plant nutrients and can cause plant life and algae to grow quickly. When plants grow quickly, they also die quickly. This contributes to the organic waste in the water, which is then decomposed by bacteria. This results in a high BOD level. ${ }^{18}$ When BOD levels are high, dissolved oxygen (DO) levels decrease because the oxygen that is available in the water is being consumed by the bacteria. Since less dissolved oxygen is available in the water, fish and other aquatic organisms may not survive. ${ }^{19}$

According to a recent UNIDO report,$^{20}$ the treatment of tannery effluents is by now a well established technology, and modular common effluent treatment plants servicing traditional tannery 
clusters or newly created leather industry zones is a widely accepted approach. However, two issues still pose serious challenges.

High total dissolved solids, TDS, unaffected by treatment. This problem is especially pronounced in developing countries where mixing tannery effluent with domestic sewage or its discharge into the sea is not feasible, and the raw hides and skins are still preserved by salting. Relocation of tanneries to the seaside is often not feasible, and desalination of treated effluent by reverse osmosis is very expensive. However, utilization or safe disposal of sludge, cost-effective solutions to both of these problems are still eagerly awaited.

The conventional treatment system marginally removes the organic pollutant where as it failed to remove total dissolved solids. The treated water it can be understand that the treated water can be reused for the process. The rejects obtained in the process is subjected to solar evaporation system or multiple evaporation system for further recovery of salt. ${ }^{21}$ The design of experiment system provides a valuable approach to study effects of multiple variables on the performance of various processes. Studies on environmental issues benefited well from the system and many examples may be presented here. DelgadoMoreno et al. ${ }^{22}$ studied the extraction of triazines from soil after olive cake amendment. Experimental design was successfully employed to evaluate the optimal conditions on the removal of oxytetracycline and heavy metals from water. ${ }^{23,24}$ The systems presents a systematic approach for the effects of simultaneous variables at several levels and allows the evaluation of the applicability of the proposed model.

The present work is an attempt to apply the design of experiments approach to shed more light on the pollution potential of a state tanning factory, South of Baghdad, Iraq. The BOD5 is taken as a parameter to indicate the optimum condition of biological treatment in ASP.

\section{Materials and methods}

\section{Materials}

Phosphoric acid (70wt \%) was supplied by a local company. The chemicals used for the determination of BOD5 and phosphate were of analytical grade. An agar was prepared for the growth of bacteria, and consists of: beef extract, $3 \mathrm{~g}$; peptone, $5 \mathrm{~g}$; agar, $15 \mathrm{~g}$ and distilled water to make a volume of one liter. The $\mathrm{pH}$ of the culture media was 7.0.

Malt extract agar was used to grow fungi. it consists of: malt extract, $20 \mathrm{~g}$; peptone, $5 \mathrm{~g}$, agar, $15 \mathrm{~g}$ and distilled water to make a volume of one liter. Culture media: $\mathrm{pH}=3.5-4.0$.

\section{Laboratory treatment units}

Figure 1 shows a schematic diagram of the experimental unit used for the biochemical wastewater treatment. The unit consists of:

A temperature regulated water bath of $(60 \mathrm{~cm} \times 40 \mathrm{~cm} \times 16 \mathrm{~cm})$ and $1.2 \mathrm{~kW}$ power was equipped with a stainless steel electrical stirrer $(1.2 \mathrm{~kW})$ and coupled with voltage variac box. The clarifier was a 3-liter Pyrex flask with a discharge valve at the bottom and a tap near the top, for the collection of treated wastewater. Air was introduced via a pre-calibrated rotameter with and an air sparger to ensure even distribution. A Pyrex burette was used for the delivery of nutrient (phosphoric acid).

Some supplementary equipment were used including an incubator (Memmert, Germany); a microscope (Olympus); an autoclave for sterilization (Express, England); a Digital Grating Spectrophotometer (Pye unicam, England); and a Universal Pocket Meter Multiline P4 including: I. $\mathrm{pH}$ combined electrode with integrated temperature probe Sen tix 41; and II. Dissolved oxygen (DO) probe, Cell Ox 325.

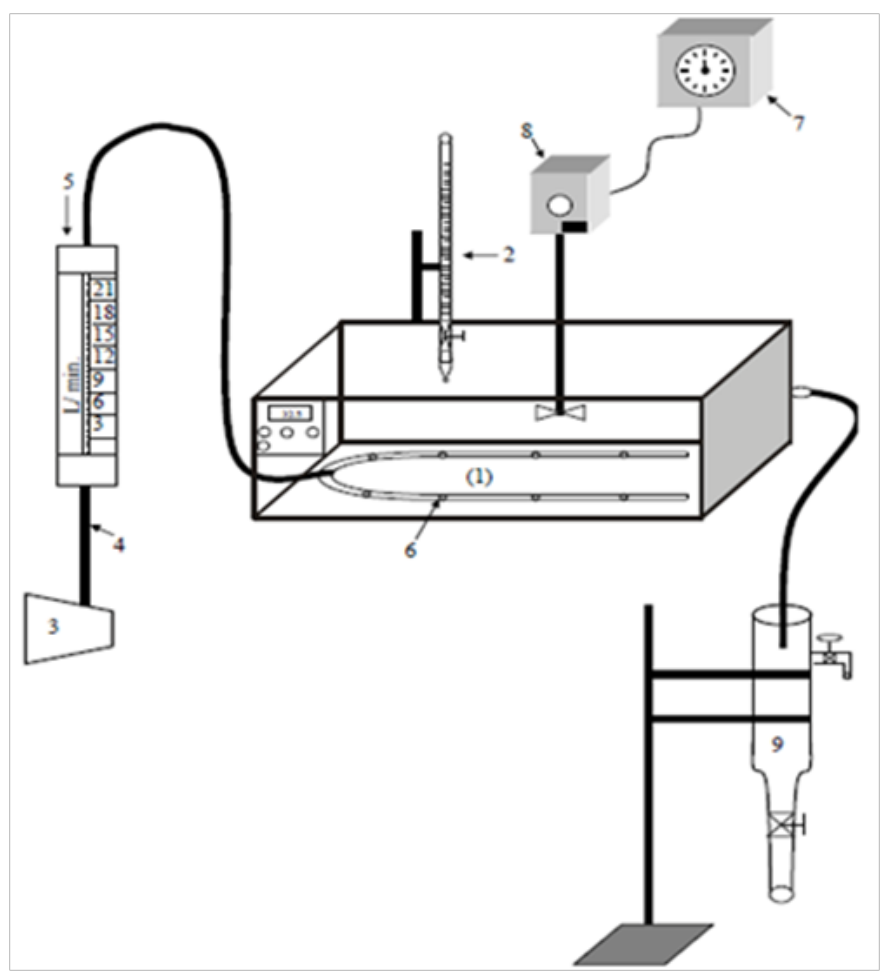

Figure I Schematic diagram of the experimental system: I: Water bath; 2: Burette; 3: Compressor; 4: Pipes; 5: Rotameter; 6: Air sparger; 7: Voltage Controller Box; 8: Stirrer and 9: Clarifier.

\section{Procedure}

The samples were taken from outline area from the wastewater of the vegetable and chrome tannery, in equal volumes. The samples were first screened to remove hair and skins pieces and then neutralized by adding sulphuric acid (50wt \%) to a final $\mathrm{pH}$ of (7-9). Sedimentation (settling) process was then carried out to reduce the solid content to about $65 \%$ within $2-3 \mathrm{~h}$. A specified volume of the sample (30Lit) was placed in the bath. The microorganism (activated sludge) where added to the water sample in the bath, and aeration was started. Following the Box-Wilson method of experimental design the operating parameters used, were in the range;

\section{$\mathrm{T}=20-45 \mathrm{oC} ; \mathrm{t}=5-10$ hour $\mathrm{PO} 4$ concentration=5-20mg/Lit}

After the biochemical treatment, a polyelectrolyte at a rate of $15 \mathrm{mg} / \mathrm{L}$ was added to the mixture in the bath for a period of one hour to improve the process of sedimentation. In the natural sedimentation stage, the sample was taken from the bath and clarified for about $3 \mathrm{~h}$, and then a specified volume of the clarified water was taken for the BOD5 measurement.

\section{Methods of examination}

The TSS and volatile suspended solids (VSS) tests were done according to the WHO methods for pollution control, 1982. The (DO) concentration was measured using a (Cell DX 325) type device, which consists of a gold-metal electrode (Wissen Schuftliche Tech. Werk., Germany). The accuracy of this method is $(0.1 \mathrm{mg} / \mathrm{Lit})$. The readings were checked versus titration method. The titration was carried out using standard $0.025 \mathrm{~N}$ sodium thiosulfate and starch as an indicator. 
The dilution, the BOD5 measurement and the determination of the phosphate concentration were carried out in accordance with standard methods. ${ }^{25}$ To perform bacteriological tests, the preparation of agar plate as well as the isolation of discrete colonies from a mixed culture was carried out according to the published methods. ${ }^{26}$

\section{Results and discussion}

This work deals with effect of three variables (temperature, aeration period and phosphate concentration) on BOD5.

\section{Postulating the mathematical model}

A second order polynomial equation was employed in the range of the independent variables. Three variables were considered. The general form of a $2^{\text {nd }}$ polynomial equation can be given as follows:

$\mathrm{Y}=\mathrm{B} 10+\mathrm{B} 11 \mathrm{X} 11+\mathrm{B} 12 \mathrm{X} 12+\mathrm{B} 13 \mathrm{X} 13+\mathrm{B} 14 \mathrm{X} 213+\mathrm{B} 15 \mathrm{X} 212+\mathrm{B} 16$ $\mathrm{X} 213+\mathrm{B} 17 \mathrm{X} 11 \mathrm{X} 12+\mathrm{B} 18 \mathrm{X} 11 \mathrm{X} 13+\mathrm{B} 19 \mathrm{X} 12 \mathrm{X} 13$

The coded and real variables as well as the real values of BOD5 are given in Table 1. The data of Table 1 were fitted to equation (1) so that the regression analysis of central composite design to the approximating model to obtain the optimum conditions of the process. The coefficients of polynomial equation were evaluated. Thus, the best form of equation 1 is:

$\mathrm{Y}=288.498+34.846 \mathrm{X} 11+18.289 \mathrm{X} 12+9.892 \mathrm{X} 13+36.896 \mathrm{X} 211+9$ $151 \mathrm{X} 212+7.317 \mathrm{X} 213+5 \mathrm{X} 11 \mathrm{X} 12+3.75 \mathrm{X} 11 \mathrm{X} 13+3.749 \mathrm{X} 12 \mathrm{X} 13$

Correlation coefficient, $\mathrm{R}=0.977$,

Percentage square error $(\mathrm{S})=1.8 \%$.

Table I The coded and real variables of the calculations Of BOD5 using central composite method

\begin{tabular}{|c|c|c|c|c|c|c|c|}
\hline \multirow{2}{*}{$\begin{array}{l}\text { Exp } \\
\text { no. }\end{array}$} & \multicolumn{3}{|c|}{ Coded Variable } & \multicolumn{3}{|c|}{ Real Variable } & \multirow[b]{2}{*}{$\mathrm{BOD}_{5}$} \\
\hline & $x_{11}$ & $x_{12}$ & $x_{13}$ & $\mathrm{x}_{11},{ }^{\circ} \mathrm{C}$ & $\begin{array}{l}x_{12}, \\
h r\end{array}$ & $\begin{array}{l}x_{13}, \\
\text { mg/Lit }\end{array}$ & \\
\hline I & -1 & -1 & -1 & 25.3 & 6 & 8.2 & 350 \\
\hline 2 & 1 & -1 & -1 & 39.7 & 6 & 8.2 & 420 \\
\hline 3 & -1 & I & -1 & 25.3 & 9 & 8.2 & 300 \\
\hline 4 & I & I & -1 & 39.7 & 9 & 8.2 & 385 \\
\hline 5 & -1 & -1 & 1 & 25.3 & 6 & 16.8 & 330 \\
\hline 6 & I & -1 & 1 & 39.7 & 6 & 16.8 & 380 \\
\hline 7 & -1 & I & 1 & 25.3 & 9 & 16.8 & 290 \\
\hline 8 & I & I & 1 & 39.7 & 9 & 16.8 & 365 \\
\hline 9 & -1.732 & 0 & 0 & 20 & 7.5 & 12.5 & 325 \\
\hline 10 & 1.732 & 0 & 0 & 45 & 7.5 & 12.5 & 445 \\
\hline II & 0 & -1.732 & 0 & 32.5 & 5 & 12.5 & 335 \\
\hline 12 & 0 & 1.732 & 0 & 32.5 & 10 & 12.5 & 268 \\
\hline 13 & 0 & 0 & -1.732 & 32.5 & 7.5 & 5 & 310 \\
\hline 14 & 0 & 0 & 1.732 & 32.5 & 7.5 & 20 & 288 \\
\hline 15 & 0 & 0 & 0 & 32.5 & 7.5 & 12.5 & 288 \\
\hline 16 & 0 & 0 & 0 & 32.5 & 7.5 & 12.5 & 290 \\
\hline 17 & 0 & 0 & 0 & 32.5 & 7.5 & 12.5 & 288 \\
\hline 18 & 0 & 0 & 0 & 32.5 & 7.5 & 12.5 & 288 \\
\hline 19 & 0 & 0 & 0 & 32.5 & 7.5 & 12.5 & 288 \\
\hline 20 & 0 & 0 & 0 & 32.5 & 7.5 & 12.5 & 288 \\
\hline
\end{tabular}

To test the significance of each term in equation (2), the Fdistribution test was used employing the variance of each term in multivariable correlation, according to (Table 1). ${ }^{27}$ The calculations indicated insignificant interaction between the variables (X1X3, $\mathrm{X} 1 \mathrm{X} 2, \mathrm{X} 2 \mathrm{X} 3$ ) are. Thus the best form of the relationship is

$\mathrm{Y}=288.498+34.846 \mathrm{X} 11+18.289 \mathrm{X} 12+9.892 \mathrm{X} 13+36.896 \mathrm{X} 211+9$ $151 \mathrm{X} 212+7.317 \mathrm{X} 213$

The optimization process 28 was applied to equation (2) to find the optimum operating conditions and the results indicate the following conditions to attain the minimum BOD $5=256 \mathrm{mg} / \mathrm{L}$ :

$\mathrm{X} 11=$ Temperature $=32.5^{\circ} \mathrm{C}$,

$\mathrm{X} 12=$ Aeration period $=10 \mathrm{~h}$,

$\mathrm{X} 13=$ Phosphate concentration $=16.8 \mathrm{mg} / \mathrm{L}$.

\section{Effect of operation variables on $\mathrm{BOD}_{5}$}

Effect of temperature: Figure 2 shows the influence of temperature on BOD5 at different aeration periods at fixed phosphate concentration $(16.8 \mathrm{mg} / \mathrm{L})$. It is clear that, the BOD5 decreases with increasing temperature down to a value of $250 \mathrm{mg} / \mathrm{Lit}$ at $32.5^{\circ} \mathrm{C}$ and aeration period of $10 \mathrm{~h}$. Beyond this temperature, the BOD5 values increase.

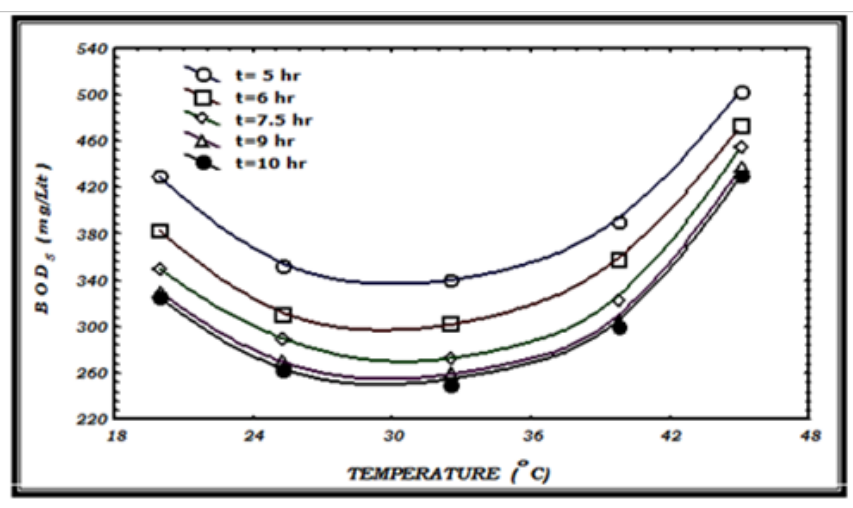

Figure 2 Effect of Temperature on $\mathrm{BOD}_{5}$ at Fixed Phosphate Concentration $(16.8 \mathrm{mg} / \mathrm{L})$.

Figure 3 shows the effects of temperature on BOD5 at various phosphate concentrations and constant aeration period of $10 \mathrm{~h}$. The BOD5 reached a value of $250 \mathrm{mg} . \mathrm{L}^{-1}$ at temperature of $32.5^{\circ} \mathrm{C}$ and phosphate concentration of $16.8 \mathrm{mg} / \mathrm{L}$. Figure 4 shows the response surface function developed by the model considering temperature and aeration period. The response obtained is minimum BOD5 at temperature of $32.5^{\circ} \mathrm{C}$ and aeration period of $10 \mathrm{~h}$.

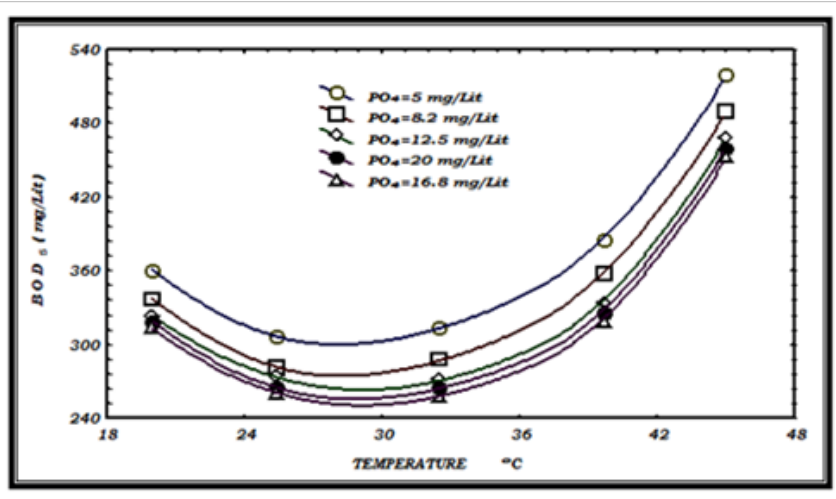

Figure 3 Effect of Temperature on $\mathrm{BOD}_{5}$ at Fixed Aeration Period ( $\left.10 \mathrm{hr}\right)$. 


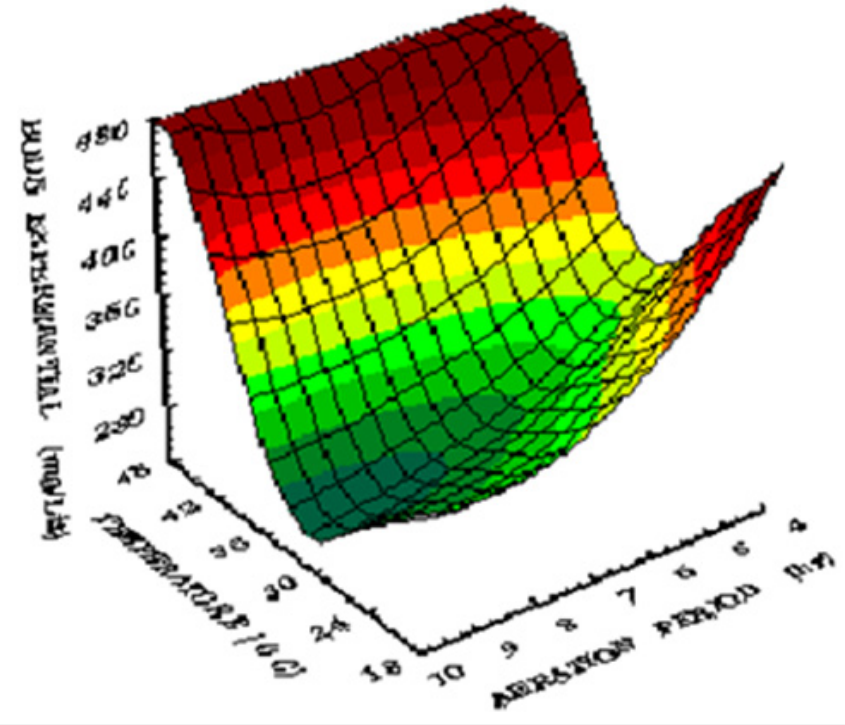

Figure 4 Response surface of the combined effects of Temperature and Aeration Period on $\mathrm{BOD}_{5}$.

It is clear that increasing in temperature from $20^{\circ} \mathrm{C}$ to $32.5^{\circ} \mathrm{C}$, leads to an increase in the activity of microorganisms to degrade the organic material. Beyond $32.5^{\circ} \mathrm{C}$, the activity of microorganism decreases. ${ }^{14,28,29}$ The trend agrees with the theory which states that the BOD5 reaction rate coefficient and the concentration of organic material in start reaction are directly affected by temperature, as given by the following equation:

$\mathrm{BOD}=\mathrm{L} 0(\mathrm{~T})(1-10-\mathrm{KTt})$

Where, according to Van't Hoff-Arrhenius law

$\mathrm{KT}=\mathrm{K} 20 \theta(\mathrm{T}-20)$

and

$$
\mathrm{L} 0(\mathrm{~T})=\mathrm{L} 0(20)(1+0.02(\mathrm{~T}-20))
$$

The constant $\theta$, as given by Euiso28 is equal to 1.047. Equations (5) and (6), thus, indicate that the increase in temperature influence the reaction rate coefficient and the concentration of organic material at the start reaction. Hence, the increase in temperature until $32.5 \mathrm{Co}$ would increase $\mathrm{KT}$ and $\mathrm{Lo}(\mathrm{T})$ and reduces BOD. ${ }^{29}$

\section{Effect of aeration period}

The effects of the aeration period on the BOD5 at various temperatures and phosphate concentration are shown in Figures $5 \& 6$, respectively. The BOD5 values decrease with the increase of aeration period and reaches $250 \mathrm{mg} / \mathrm{L}$ at a temperature of $32.5^{\circ} \mathrm{C}$ at a fixed phosphate concentration of $16.8 \mathrm{mg} / \mathrm{L}$ (Figure 5). Figure 6 indicates that aeration period of $10 \mathrm{~h}$ is enough to drop the BOD5 value down to $250 \mathrm{mg} / \mathrm{L}$ at a phosphate concentration of $16.8 \mathrm{mg} / \mathrm{Lit}$ and constant temperature of $32.5^{\circ} \mathrm{C}$. The increase in the aeration period to a certain limit lowers both the BOD5 and the MLSS, since there will be longer time for the microorganism to decompose the organic matter into simpler materials. ${ }^{30}$

However, the increase in the oxygen supply above this limit will improve the growth and reproduction of the microorganism and needed high cost for aeration basin. ${ }^{29}$ The competition between these microorganism for nutrient, may lead to starvation and thus a reduction in the number of microorganism. ${ }^{31}$

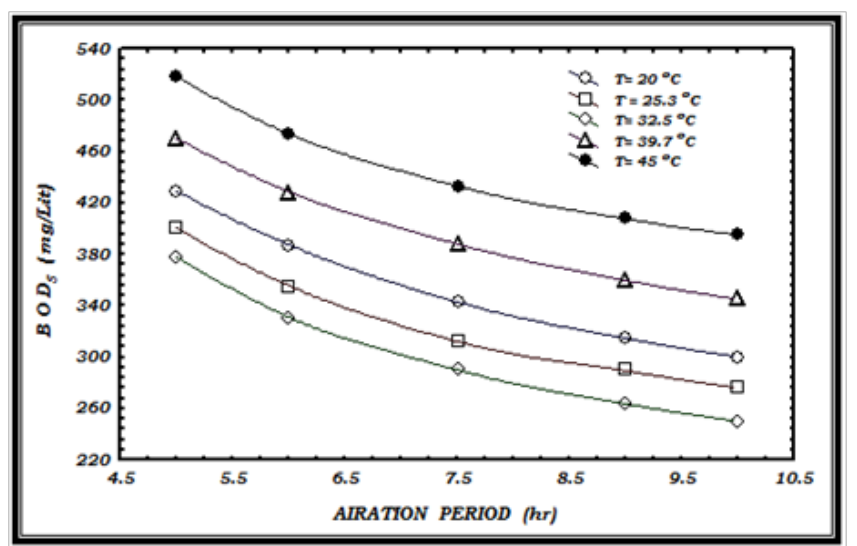

Figure 5 Effect of Aeration Period on $\mathrm{BOD}_{5}$ at Fixed Phosphate Concentration (16.8mg/L).

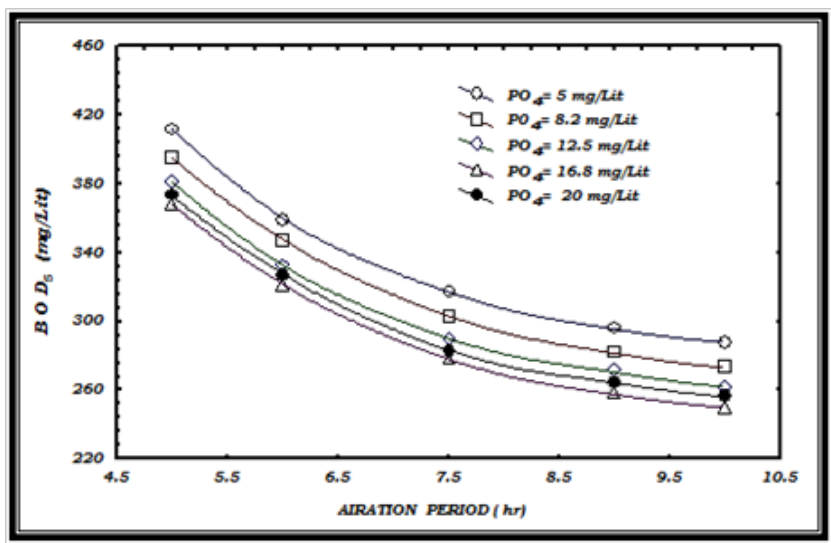

Figure 6 Effect of Aeration Period on BOD5 at Fixed Temperature $\left(32.5^{\circ} \mathrm{C}\right)$.

\section{Effect of phosphate}

Figure 7 shows the influence of phosphate concentration on BOD5 at different temperatures using constant aeration period of $10 \mathrm{~h}$. The BOD5 reaches a value of $250 \mathrm{mg} / \mathrm{L}$ at phosphate concentration of $16.8 \mathrm{mg} / \mathrm{L}$ and at a temperature of $32.5^{\circ} \mathrm{C}$. Figure 8 shows the influence of phosphate concentration on BOD5 at various aeration periods and constant temperature. The BOD5 decreases when phosphate concentration increases up to a level of $16.8 \mathrm{mg} / \mathrm{L}$. Beyond this level, the BOD5 increases slowly since more phosphate concentration helps algae growth. When these algae die and decay they give organic material which increases the BOD5. Thus it may be assumed that, the input of $1 \mathrm{mg}$ phosphorus lead to the growth of about $100 \mathrm{mg}$ of algae dry matter. ${ }^{32}$ Figure 9 shows isometric relationship of the BOD5 with aeration period and phosphate concentration. The response obtained is minimum (BOD5) at aeration period $10 \mathrm{~h}$ and phosphate concentration of $16.8 \mathrm{mg} / \mathrm{L}$.

Microorganisms require certain nutrients for growth. The basic nutrients of abundance in normal raw sewage are carbon (C), nitrogen $(\mathrm{N})$ and phosphate $(\mathrm{P})$ with the ratio of $\mathrm{C}: \mathrm{N}: \mathrm{P}$ of approximately 100:10:1. ${ }^{32}$ Phosphorus is an essential element, it is part of the structure of DNA and RNA, and is an important intermediate in metabolism. ${ }^{31}$

Bacteriological tests indicated the presence of bacteria and protozoa in the ASP. The types of bacteria found on the surface after incubation were: I. Staphylo cocci spp. and II. Bacilli. Meanwhile, fungi did not appear on culture, since they favor $\mathrm{pH}$ lower than the $\mathrm{pH}$ of ASP 


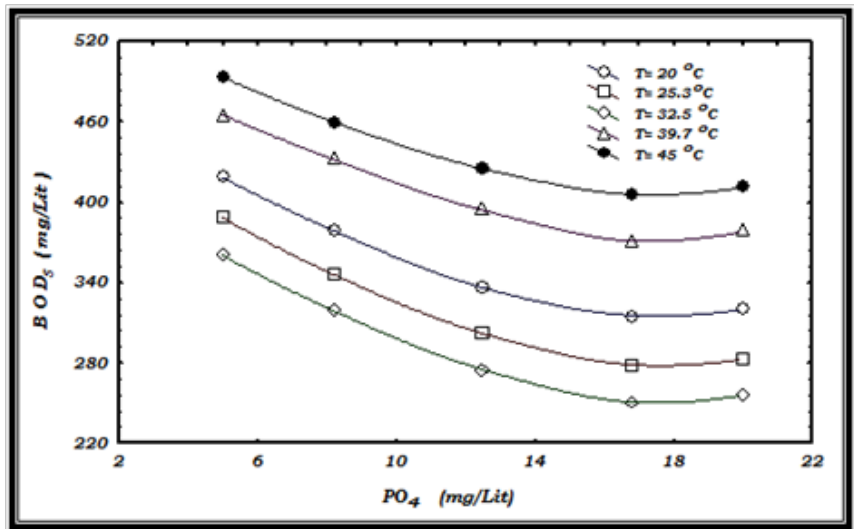

Figure 7 Effect of Phosphate Concentration on $\mathrm{BOD}_{5}$ at Fixed Aeration Period ( $10 \mathrm{hr})$.

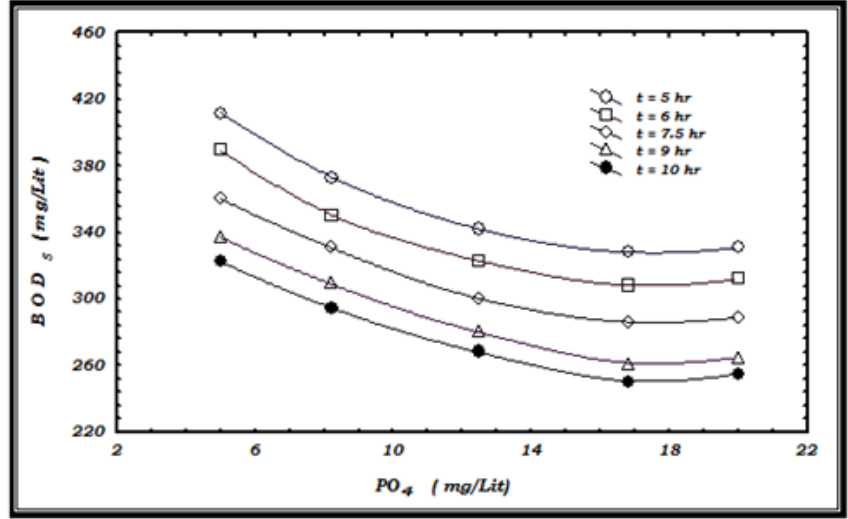

Figure 8 Effect of Phosphate Concentration on BOD5 at Fixed Temperature $\left(32.5^{\circ} \mathrm{C}\right)$

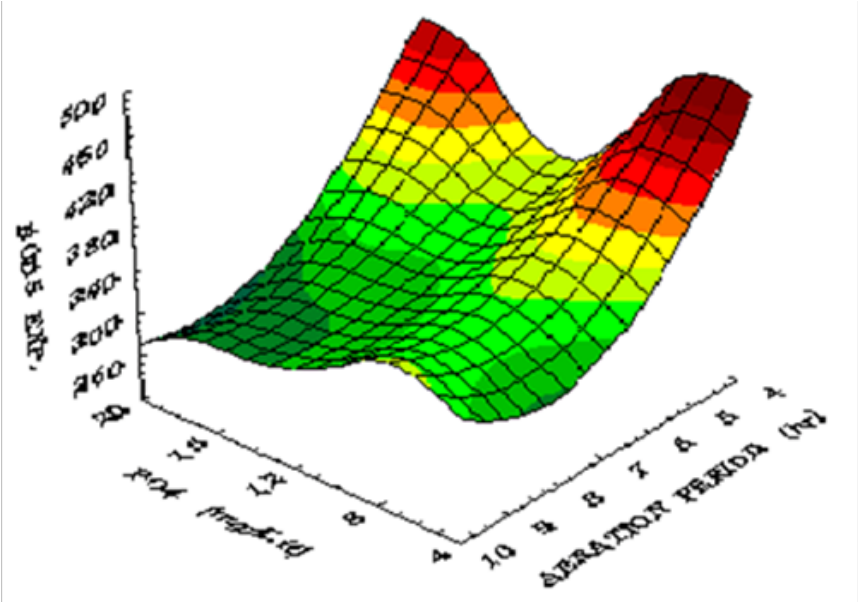

Figure 9 Response surface of the combined effects of Aeration Period and Phosphate Concentration on $\mathrm{BOD}_{5}$.

\section{Applications of optimum condition for wastewater treatment plant}

After carrying out the preliminary processes, the wastewater samples were taken from the effluent of two tanneries, with their BOD5 values reduced from $760 \mathrm{mg} / \mathrm{L}$ to $610 \mathrm{mg} / \mathrm{L}$. The optimum conditions that have been obtained above (Temperature $=32.5^{\circ} \mathrm{C}$; Aeration period $=10 \mathrm{~h}$; and Phosphate concentration $=16.8 \mathrm{mg} / \mathrm{L}$ ) were used for the biochemical treatment. The treatment resulted in a decrease in the BOD5 form $436 \mathrm{mg} / \mathrm{Lit}$ to $75 \mathrm{mg} / \mathrm{L}$ in laboratory. However, the actual BOD5 value of the effluent from the first aeration basin in plant was $100 \mathrm{mg} / \mathrm{L}$.

\section{Conclusion}

The biochemical treatment of vegetable tannery wastewater can be best performed at the following conditions: Temperature, $32.5^{\circ} \mathrm{C}$; Aeration period $10 \mathrm{hr}$ and Phosphate concentration, $16.8 \mathrm{mg} / \mathrm{L}$. With such conditions, The BOD5 value could be reduced from $436 \mathrm{mg} / \mathrm{L}$ down to a value of $30 \mathrm{mg} / \mathrm{L}$. Only bacteria and protozoa were found as microorganisms in the activated sludge, because the alkaline condition and unaeration are not suitable for the living of fungi. Waste water treatment with Reverse Osmosis technology is the best option for treating high conductivity of global waste water from tannery industry. Feasibility of reusing tannery waste water by combinations of existing conventional activated sludge process, with Ultra filtration, Nano filtration and Reverse Osmosis treatment technologies were studied. ${ }^{20}$

\section{Acknowledgements}

None.

\section{Conflict of interest}

The author declares no conflict of interest.

\section{References}

1. FAO. United Nation food and Agriculture Organization Journal. 1999.

2. Koziorowski B, Kucharski J. Industrial Waste Disposal. 1st English ed. Poland: Wydawnictwa NauKowo-Techniczne; 1972.

3. American Water Works Association. Water Quality and Treatment. 1990.

4. Droste RL. Theory and Practice of Water and Wastewater Treatment. USA: John, Wiley and Sons; 1997.

5. http.//webmall.Ucbiz.Com/powercontents/water/wastewater,html

6. Barbooti MM, Zablouk MA, Al-zubaidi UA. Inter J Indust Chem. 2010;1:29-38.

7. Mark JH. Water and Wastewater Technology. 2nd ed. USA: John Wiley and Sons Inc; 1986.

8. Matcalfe, Eddy. Wastewater Engineering. India: McGraw Hill Inc; 1991.

9. Tebbutt THY. Principles of Water Quality Control. 2nd ed. London: Pergamon Press Ltd; 1977.

10. Nemerow NL. Liquid Waste of Industry. USA: Addison-Wesley Publishing company Inc.; 1971.

11. Besscliovro E. The Treatment of Industrial Wastes. 2nd ed. USA: Mc Graw Hill Book Co; 1976.

12. Kashiwaya M, Yoshimato K. J Water Poll Cont Fed. 1981;52:32-33.

13. Watts J, Garber B. Respirometric Control of the Activated Sludge Process. Proc. Sensors in Wastewater Technology Conf. 1995.

14. Duke ML, Eckenfelder WW, Templeton M. J Water Sci Technol. 1981;14:20-22.

15. Robert J, Linda L. The Microbiology of Activated Sludge. India: Walters Kluwer Co; 1998.

16. Eye JD. Tannery Wastes. J Water Poll Cont Fed. 1978;48:81-83. 
17. Sawyer CN, McCarty PL, Parkin GF. Chemistry for Environmental Engineering and Science. 5th ed. USA: New York; 2003.

18. Mllanov P. Biological Oxygen Demand-5day total demand (BOD5). Canada: University of Toronto; 2000.

19. Negulescu M. Municipal Wastewater Treatment. Elsevier Science Publishers; $1986.93 \mathrm{p}$

20. UNIDO. Introduction to treatment of tannery effluents. Austria: united Nations industrial development organization; 2011.

21. Krishnamoorthi S, Saravanan K, Priyenka Devi KS. Integrated effluent treatment in tannery industries- feasibility study. $J$ Industrial Poll Control. 2011;27(2):1-5.

22. Delgado-Moreno L, Peña A, Mingorance MD. Design of experiments in environmental chemistry studies: example of the extraction of triazines from soil after olive cake amendment. J Hazard Mater. 2009;162(23):1121-1128.

23. Barbooti MM. Simultaneous removal of chromium and lead from water by sorption on iraqi montmorillonite $J$ Environmental Protection. 2015;6(3):236-247.

24. Barbooti MM, Su H, Punamiya P, et al. Oxytetracycline sorption onto Iraqi montmorillonite. Int J Environ Sci Technol. 2014;11(1):69-76.

25. Eaton AD, Franson MAH. Standard Methods for The Examination of Water \& Wastewater. Amer Water Works Assoc., Water Environment Federation; 2005.
26. Cappuccino G, Sherman N. Microbiology: Laboratory Manual. USA: Benjamin/Cummings publishing Co; 1987.

27. Montgomery DC. Design and Analysis of Experiments. USA: Wiley; 1976.

28. Kriton C, Wesley W. Theory and Practice of Biological Wastewater Treatment. 1980.

29. Euiso C, Euisin Lee. Temperature effects on biological nutrient removal system with weak municipal wastewater. Water Sci Technol. 1998;37(9):219-220.

30. Droste RL. Theory and Practices of Water and Wastewater Treatment. USA: John Wiley and Sons; 1997. p. 239-241.

31. Grega MD, Evans JC. Waste Management. USA: McGraw Hill Inc; 1994.

32. Warren J, Mark JH. Water Supply and Pollution Control. 4th ed. USA: Harper and Row Publishers Inc; 1985.

33. Kristensen GH, Jorgensen PE, Henze M. Characterization of functional groups and substrate in activated sludge and wastewater by AUR, NUR and OUR. Water Sci Technol. 1992;25(6):43-57.

34. Cooper P, Day M, Thomas V. Process Option for Phosphorus and Nitrogen Removal from Wastewater. Water and Environ J. 1994;8(1):84-92. 